\title{
IMPACTS OF COMPOST, BIOFERTILIZER AND/OR SOME ANTIOXIDANT TREATMENTS ON GLADIOLUS (GLADIOLUS GRANDIFLORAS) A. VEGETATIVE GROWTH AND FLOWERING ASPECTS
}

\author{
A.A. Hassan* and M.M. Abd El-Azeim** \\ * Horticultural Science Department, Faculty of Agriculture, Minia University, Egypt \\ ** Soil Science Department, Faculty of Agriculture, Minia University, Egypt

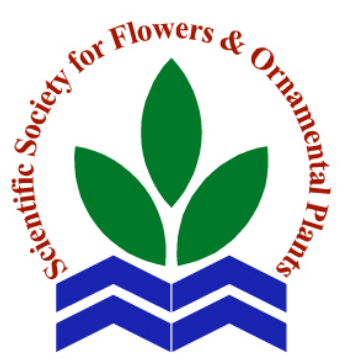 \\ Scientific J. Flowers \& \\ Ornamental Plants, \\ 7(3):269-283 (2020). \\ Received: \\ 3/8/2020 \\ Accepted: \\ 25/8/2020 \\ ABSTRACT: A field experiment was carried out during two \\ successive seasons of 2018/2019 and 2019/2020 at the Nursery of \\ Ornamental plants, Faculty of Agriculture, Mania University. The aim \\ of this study was to investigate impacts of compost at four levels $(0,5$, \\ 10 and 15 ton/fed) in combination with Microbein biofertilizer (M.B.) \\ at $50 \mathrm{ml} /$ plant and/or some antioxidant treatments (salicylic and \\ ascorbic acids) on vegetative growth and flowering of Gladiolus \\ grandiflorus var. Jester plants. Results showed that vegetative growth \\ and flowering parameters of leaf length $(\mathrm{cm})$, number of leaves/plant, \\ leaves dry weight/plant (g), length of spike ( $\mathrm{cm})$, spike diameter $(\mathrm{mm})$, \\ spike fresh weight (g), number of florets/spike, lower floret diameter \\ (cm) and lower floret fresh weight (g) were gradually increased with \\ significant differences by increasing levels of compost. In addition, \\ Microbein biofertilizer (M.B.) and/or some antioxidant (salicylic and \\ ascorbic acids) treatments significantly increased all vegetative growth \\ and flowering parameters in comparison with control treatment. \\ Microbein biofertilizer plus salicylic acid and ascorbic acid were more \\ effective in this concern. It was found also that the use of compost (15 \\ ton/fed) in combination with Microbein biofertilizer plus salicylic acid \\ plus ascorbic acid followed by 15 ton/fed with M.B. plus ascorbic acid \\ then 10 ton/fed with M.B. plus salicylic acid plus ascorbic acid \\ noticeably improved different vegetative growth characters and \\ flowering parameters of gladiolus plants. As the most important \\ characters for the quality of gladiolus, the largest length of spike \\ (season one $65.76 \mathrm{~cm}$ and season two $65.76 \mathrm{~cm}$ ), largest number of \\ florets/spike (season one 11.65 and season two 11.98) and the highest \\ lower floret diameter (season one $7.79 \mathrm{~cm}$ and season two $8.34 \mathrm{~cm}$ ) \\ were achieved with compost (15 ton/fed) in combination with \\ Microbein biofertilizer plus salicylic acid plus ascorbic acid. From the \\ results of this study, it could be concluded that adaptability of \\ gladiolus corms of Jester variety (Gladiolus gradiflorus) to the \\ Egyptian environmental conditions is confirmed.
}

Key words: Microbein biofertilizer, gladiolus, flowering, antioxidant.

\section{INTRODUCTION}

Gladiolus (sword lily) is known as queen of bulbous flowers due to their elegant attractive spikes of different hues, varying sizes and long vase life (Jabbar et al., 2018). Gladiolus (Gladiolus grandiflorus, L.) is an important cut flower belongs to Iridaceae family. Gladiolus occupies fourth place in the international trade after rose, carnation 


\section{A.A. Hassan and M.M. Abd El-Azeim}

and chrysanthemum, in the cut flower industry (Tirkey et al., 2017). Gladiolus is derived from the native plants of south and central Africa, as well as, the Mediterranean region (De-Hertogh and Le Nard, 1995). The importance of gladiolus as cut flowers is increasing day by day in domestic, as well as, international market. It is also ideal both for garden display and floral arrangements for table and interior decoration as well as making high quality bouquet (Lepcha et al., 2007).

Organic, Microbein biofetilizer (M.B.) and some antioxidants (salicylic and ascorbic acids) are among the important agricultural treatments which have been proved to improve the vegetative growth and flowering aspects of gladiolus plants. Many investigators revealed the importance of organic fertilization on the growth and flowering of gladiolus such as Chandar et al. (2012), Pandey et al. (2013), Abdou and Ibrahim (2015), Abdou et al. (2018), Baruati et al. (2018) and Beck et al. (2019) on gladiolus plants, Kabir et al. (2011), Srivastava et al. (2014), Pattnaik (2016) and Preetham et al. (2017) on tuberose plant, Kiran et al. (2013) and Pandey et al. (2017) on dahlia and Rajaei and Onsinejad (2014) on tulip plant. The role of Microbein biofertilizer (M.B.) in improving vegetative growth and flowering parameters was revealed by Dalve et al. (2009), Kaushik et al. (2016), Zehra et al. (2017), Sathyanarayana et al. (2018) and Bohra and Nautiyal (2019) on gladiolus, Kumar et al. (2012), Attia et al. (2018) and Avinash et al. (2019) on tuberose, Fayaz et al. (2018) on tulip plant. The role of ascorbic acid (vit. C) in improving vegetative growth and flowering characters was also mentioned by Abdel Aziz et al. (2009), Abo Leila and Eid (2011) and Khalil (2015) on gladiolus, Kasim and Adil (2014) on Freesia hybrid, Mohammed et al. (2016) on dahlia plant and Gaber (2019) on Pelargonium zonale plant.

One of the most important quality factors of each cut flower is the post-harvest life. Application of benzyladenine (BA) and salicylic acid (SA) reduces ethylene production and thus increases the longevity of cut flowers. SA also reduces the effects of biotic and abiotic stresses such as heat, salinity, and drought (Abbasi et al., 2020). The plant growth regulators (PGRs) increase the antioxidant capacity of cells, and this mechanism could possibly reduce the aging process in the harvested crops and cut flowers. Therefore, the application of SA in cut flowers can influence the antioxidant system and increase the vase life (Ezhilmathi et al., 2007). The use of 5-sulfosalicylic acid in gladiolus cut flowers increases water absorption, vase life, and number of open florets and also reduces the number of unopened florets compared with control samples (Ezhilmathi et al., 2007). Furthermore, it has been reported that the application of SA increased the vase life and body weight and diameter of flower in Samurai cultivar of rose flowers, but adversely affected the percentage of flower opening (Abbasi et al., 2020).

The role of salicylic acid in increasing vegetative growth and flowering parameters was reported by Pal et al. (2015), Tamrakar et al. (2018) and Al-Hasnawi et al. (2019) on gladiolus, Ahmad et al. (2018) and Nassour et al. (2019) on tuberose, Kumari et al (2018) on lily, Ramzan et al. (2018) on iris, Aashutosh et al. (2019) on chrysanthemum plant.

Jester variety (yellow flowers) of gladiolus corms (Gladiolus gradiflorus) is a well-known variety for its adaptability to the Egyptian environmental conditions as well increased high potentials of its flowers exporting. Therefore, the aim of this work was to study the effects of compost, Microbein biofertilizer (M.B.) and/or some antioxidant (salicylic and ascorbic acids) treatments on the vegetative growth and flowering of gladiolus (Gladiolus grandiflorus, L.) var. Jester plants.

\section{MATERIALS AND METHODS}

A field experiment was carried out during two successive seasons of 2018/2019 
and 2019/2020 at the Nursery and Laboratory of Ornamental plants, Faculty of Agriculture, Minia University to figure out the response of Gladiolus graniflorus var. Jester plants to compost, Microbein biofertilizer (M.B.) and/or some antioxidant (salicylic and ascorbic acids) treatments. The corms of gladiolus were imported from Holland by Basiony Nurseries, Cairo, Egypt. Average corm diameter was 2.6 and $3.2 \mathrm{~cm}$ and corm weight were 9.5 and $10.4 \mathrm{~g}$ for the first and second seasons, respectively, all corms were soaking for one minute in Pinilate (fungicide) at the concentration of 1 g/l before planting in both successive experimental seasons. For both seasons, on $1^{\text {st }}$ of October soil plots $(1.5 \times 2.0 \mathrm{~m})$ were prepared then corms were implanted in hills, $20 \mathrm{~cm}$ apart, each plot contains 3 ridges, 50 $\mathrm{cm}$ apart (10 corms/ridge). The physicochemical properties of the investigated soil in this study were determined according to Jackson (1973) and Page et al., (1982) and shown in Table (1).

The experimental design was split plot with three replicates. Four levels of compost fertilization were considered as main plots and the seven treatments of Microbein biofertilizer (M.B.) and/or some antioxidant (salicylic acid and vitamin $\mathrm{C}$ ) treatments as the sub plots. The four levels of compost were $0,5,10$ and 15 ton/fed. The sub plots were as follows: (control, salicylic acid (S.A.) at $50 \mathrm{ppm}$, ascorbic acid (vit. C) at 50 ppm, Microbein biofertilizer (M.B.) at 50 ml/plant, M.B. + S.A., M.B. + vit. C and M.B. + S.A. + vit. C). Salicylic and ascorbic acids were obtained from Shoura Company and were sprayed three times, one month and two months after planting and after flowers cut. The plants were sprayed till run off. The Microbein was obtained from laboratory of Biofertilizers, Department of Genetics, Fac. of Agric., Minia Univ., and were applied to the soil three times (one month and two months after planting and after flowers cut) around the plant roots at the rate of 50 $\mathrm{ml} /$ plant.

The compost (plant residues) was obtained from Egyptian Company for recycling solid Residues, at New El-Minia City (Organic Nile Compost). Compost was added during preparing the soil for cultivation in both experimental seasons. Nutrient composition and physicochemical properties of the investigated compost (Organic Nile Compost) are shown in Table (2).

\section{The following data were recorded:}

1. Vegetative growth traits were recorded just before flowering such as leaf length (cm), number of leaves/plant and dry weight of leaves/plant (g).

2. Flowering characters recorded were length of spike (cm), spike diameter (mm), spike fresh weight (g), number of florets/spikes, lower floret diameter $(\mathrm{cm})$ and lower floret fresh weight (g).

\section{Statistical analysis:}

Data of the experiments were subjected to the statistical analysis of variance using MSTAT-C (1986).

Table 1. Some soil physiochemical properties of the investigated soil.

\begin{tabular}{|c|c|c|c|c|c|}
\hline \multicolumn{3}{|c|}{ Soil chemical properties } & \multirow[b]{2}{*}{ Value } & \multicolumn{2}{|c|}{ Soil physical properties } \\
\hline Character & Value & Character & & Character & Value \\
\hline pH (1:2.5 water) & 7.7 & Total P $\left(\mathrm{g} \mathrm{kg}^{-1}\right)$ & 0.56 & F.C. $\%$ & 42.45 \\
\hline $\mathrm{CaCO}_{3}\left(\mathrm{~g} \mathrm{~kg}^{-1}\right)$ & 17.9 & Available P (mg kg $\left.{ }^{-1}\right)$ & 13.11 & PWP \% & 13.78 \\
\hline CEC (cmolc kg-1) & 37.87 & Total K $\left(\mathrm{g} \mathrm{kg}^{-1}\right)$ & 4.37 & WHC \% & 48.76 \\
\hline 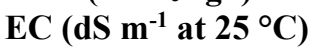 & 1.35 & Exch. $K^{+}$(mg/100 g soil) & 2.85 & A.V. (F.C. - PWP) \% & 28.67 \\
\hline OM $\left(\mathrm{g} \mathrm{kg}^{-1}\right)$ & 28.61 & Exch. $\mathrm{Ca}^{++}(\mathrm{mg} / 100$ g soil $)$ & 31.12 & A.V. (WHC-PWP) \% & 34.98 \\
\hline Total N ( kg $\left.^{-1}\right)$ & 1.29 & Exch. $\operatorname{Mg}^{++}$(mg/100 g soil) & 8.77 & Bulk density (BD) $\mathrm{g} / \mathrm{cm}^{3}$ & 1.31 \\
\hline Total $\mathrm{C} / \mathrm{N}$ ratio & 22.17 & Exch. $\mathrm{Na}^{+}(\mathrm{mg} / 100 \mathrm{~g}$ soil $)$ & 2.52 & Particle density (PD) g/cm & 2.22 \\
\hline $\operatorname{SOC}\left(\mathrm{g} \mathrm{kg}^{-1}\right)$ & 18.48 & DTPA Ext. $\left(\mathrm{mg} \mathrm{kg}^{-1}\right) \mathrm{Fe}$ & 8.23 & Sand $\%$ & 28.9 \\
\hline Organic $N\left(\mathrm{~g} \mathrm{~kg}^{-1}\right)$ & 0.76 & $\mathrm{Cu}$ & 2.01 & Silt \% & 32.8 \\
\hline Organic $\mathrm{C} / \mathrm{N}$ ratio & 24.31 & $\mathbf{Z n}$ & 2.87 & Clay $\%$ & 38.3 \\
\hline Mineral N (mg kg-1) & 58.46 & Mn & 8.11 & Soil texture & Clay loam \\
\hline
\end{tabular}


Table 2. Nutrient composition and physicochemical properties for the investigated compost.

\begin{tabular}{|c|c|c|c|}
\hline Compost property & Value & Compost property & Value \\
\hline Dry weight of $1 \mathrm{~m}^{3}$ & $450 \mathrm{~kg}$ & $\mathrm{C} / \mathrm{N}$ ratio & 26.50 \\
\hline Fresh weight of $1 \mathbf{m}^{3}$ & $650-700 \mathrm{~kg}$ & $\mathrm{~N} / \mathrm{P}$ ratio & 2.00 \\
\hline Moisture weight (\%) & $36.60 \%$ & Total P (g kg-1) (D.M.) & 5.0 \\
\hline pH (1:2.5) & 7.90 & Total K (g kg-1) (D.M.) & 9.0 \\
\hline$E C\left(d_{s} m^{-1}\right.$ at $\left.25 C^{0}\right)$ & 2.20 & Total Ca (g kg-1) (D.M.) & 26.3 \\
\hline $\mathrm{CEC}\left(\mathrm{cmol}+\mathrm{kg}^{-1}\right)$ & 45.66 & Total Mg (g kg-1) (D.M.) & 6.6 \\
\hline Dry solids \% & 63.40 & $\mathrm{NaCl}(\%)$ & $0.72-0.75$ \\
\hline Ash\% & 9.90 & $\mathrm{Fe}\left(\mathrm{mg} \mathrm{kg}^{-1}\right)$ & $150-200$ \\
\hline Total N ( $\left.\mathrm{g} \mathrm{kg}^{-1}\right)$ (D.M.) & 10.0 & $\operatorname{Mn}\left(\mathrm{mg} \mathrm{kg}^{-1}\right)$ & $25-56$ \\
\hline Total Organic Matter (\%) & $32-34 \%$ & $\mathrm{Cu}\left(\mathrm{mg} \mathrm{kg}^{-1}\right)$ & $75-150$ \\
\hline Total Organic carbon (\%) & $18.5-19.7 \%$ & $\mathrm{Zn}\left(\mathbf{m g ~ k g} \mathbf{~}^{-1}\right)$ & $150-225$ \\
\hline
\end{tabular}

Least significant difference (L.S.D) test at the probability level of $5 \%$ was used to compare the average means of treatments.

\section{RESULTS AND DISCUSSION}

\section{Vegetative growth characters:}

Data in Table (3) show that leaf length (cm), number of leaves/plant and leaves dry weight/plant (g) of gladiolus were significantly increased in both seasons due to the use of compost at 5, 10 and 15 ton/fed in comparison with those of untreated plants. The highest values were obtained from compost at the highest level of 15 ton/fed. The increase of vegetative growth resulting from using compost as organic fertilization treatment might be due to the fact that organic matter is considered as an important factor for improving physical, chemical and biological properties of the soil and consequently, increased plant growth parameters (Saber, 1997; Judais and Rinaldi, 2001 and Taiwo et al., 2002). Similar results were obtained by Ahmed (2013), Khalil (2015), Dewantier Da Cruz et al. (2018) and Kumar and Saravanan (2019) on gladiolus, El-Sayed et al. (2012) on freesia, Mirkalae et al. (2013) and Prasad et al. (2017) on lily, Srivastava et al. (2014) and Pattnaik (2016) and Karim et al. (2017) on tuberose, Abduallah (2019) on iris plant.

Data in Table (3) indicated that, leaf length $(\mathrm{cm})$, number of leaves/plant and leaves dry weight (g) were significantly increased, in both seasons, due to the use of seven treatments of Microbein biofertilizer (M.B.) and/or some antioxidant (salicylic acid and vitamin C) treatments in comparison with untreated control. The combined treatment of Microbein biofertilizer (M.B.) plus salicylic acid plus vitamin $\mathrm{C}$ seemed to be more effective than either biofertilizer alone or antioxidants. In conformity with these results were those detected by Kashyap (2016), Zehra et al. (2017), Pansuriya et al. (2018) and Bohra and Nautiyal (2019) on gladiolus, Kumar et al. (2012), Attia et al. (2018) and Avinash et al. (2019) on tuberose and Pandey et al. (2017) on dahlia plant.

The role of Microbein as biofertilizer in promoting vegetative growth might be attributed to the increase in nutrients uptake and plant contents or synthesis of plant hormone. Consequently, increasing the formation of metabolites which encourage the vegetative growth and enhance meristematic activity of cells and tissues to improve leaf production (Dadarwall et al., 1997; Hedge et al., 1999; Hauwaka, 2000 and Gadagi et al., 2004).

In plants, antioxidants were believed to protect chloroplast membranes from photooxidation and help to provide an optimal environment for the photosynthetic machinery (Munne-Bosch and Algere, 2002). The role of salicylic acid treatments in increasing vegetative growth was 
Table 3. Effect of experimental treatments on leaf length (cm), number of leaves/plant and leaves dry weight (g) of Gladiolus grandiflorus var. Jester during the first and second seasons.

\begin{tabular}{|c|c|c|c|c|c|c|c|c|c|c|}
\hline \multirow{3}{*}{ Treatments (B) } & \multicolumn{10}{|c|}{ Compost levels (ton/fed) (A) } \\
\hline & \multicolumn{5}{|c|}{$1^{\text {st }}$ season $(2018 / 2019)$} & \multicolumn{5}{|c|}{$2^{\text {nd }} \operatorname{season}(2019 / 2020)$} \\
\hline & $\mathbf{0}$ & 5 & 10 & 15 & $\begin{array}{c}\text { Mean } \\
\text { (B) }\end{array}$ & $\mathbf{0}$ & 5 & 10 & 15 & $\begin{array}{c}\text { Mean } \\
\text { (B) }\end{array}$ \\
\hline & \multicolumn{10}{|c|}{ Leaf length (cm) } \\
\hline Control & 46.11 & 47.49 & 48.92 & 50.39 & 48.23 & 47.03 & 48.44 & 49.90 & 51.40 & 49.19 \\
\hline Salicylic acid (S.A.) & 47.95 & 49.39 & 50.87 & 52.40 & 50.15 & 48.91 & 50.38 & 51.89 & 53.45 & 51.16 \\
\hline Ascorbic acid (vit. C) & 51.10 & 52.55 & 54.13 & 55.75 & 53.38 & 52.12 & 53.60 & 55.21 & 56.87 & 54.45 \\
\hline Microbein biofertilizer & 54.28 & 55.91 & 57.59 & 59.32 & 56.78 & 55.37 & 57.03 & 58.74 & 60.51 & 57.91 \\
\hline Microbein + S.A. & 57.75 & 59.48 & 61.27 & 63.11 & 60.40 & 58.91 & 60.67 & 62.50 & 64.37 & 61.61 \\
\hline Microbein + vit. C & 61.44 & 63.29 & 65.18 & 67.14 & 64.26 & 62.67 & 64.56 & 66.48 & 68.48 & 65.55 \\
\hline Microbein + S.A. + vit. C & 65.38 & 67.34 & 69.36 & 71.44 & 68.38 & 66.69 & 68.69 & 70.75 & 72.87 & 69.75 \\
\hline Mean (A) & 54.86 & 56.49 & 58.19 & 59.94 & & 55.96 & 57.62 & 59.35 & 61.13 & \\
\hline \multirow[t]{2}{*}{ L.S.D. at $5 \%$} & \multicolumn{2}{|c|}{ A:1.60 } & B:1.90 & \multicolumn{2}{|c|}{ AB:3.80 } & \multicolumn{2}{|c|}{ A:1.66 } & B:1.95 & \multicolumn{2}{|c|}{ AB:3.90 } \\
\hline & \multicolumn{10}{|c|}{ Number of leaves/plant } \\
\hline Control & 6.01 & 6.13 & 6.25 & 6.38 & 6.19 & 6.32 & 6.45 & 6.58 & 6.71 & 6.52 \\
\hline Salicylic acid (S.A.) & 6.31 & 6.44 & 6.57 & 6.70 & 6.51 & 6.64 & 6.77 & 6.91 & 7.05 & 6.84 \\
\hline Ascorbic acid (vit. C) & 6.56 & 6.71 & 6.83 & 6.97 & 6.77 & 6.81 & 6.94 & 7.09 & 7.23 & 7.02 \\
\hline Microbein biofertilizer & 6.78 & 6.91 & 7.05 & 7.19 & 6.98 & 6.98 & 7.11 & 7.26 & 7.41 & 7.19 \\
\hline Microbein + S.A. & 6.99 & 7.13 & 7.27 & 7.42 & 7.20 & 7.18 & 7.32 & 7.47 & 7.62 & 7.40 \\
\hline Microbein + vit. $\mathrm{C}$ & 7.18 & 7.32 & 7.47 & 7.62 & 7.40 & 7.37 & 7.52 & 7.67 & 7.82 & 7.60 \\
\hline Microbein + S.A. + vit. C & 7.39 & 7.53 & 7.69 & 7.84 & 7.61 & 7.60 & 7.75 & 7.91 & 8.07 & 7.83 \\
\hline Mean (A) & 6.75 & 6.88 & 7.02 & 7.16 & & 6.99 & 7.12 & 7.27 & 7.42 & \\
\hline \multirow[t]{2}{*}{ L.S.D. at $5 \%$} & \multicolumn{2}{|c|}{ A:0.09 } & B:0.06 & \multicolumn{2}{|c|}{ AB:0.12 } & \multicolumn{2}{|c|}{ A:0.11 } & B:0.07 & \multicolumn{2}{|c|}{$\mathrm{AB}: 0.14$} \\
\hline & \multicolumn{10}{|c|}{ Leaves dry weight (g) } \\
\hline Control & 1.19 & 1.68 & 2.31 & 3.15 & 2.08 & 1.61 & 2.29 & 2.98 & 3.69 & 2.64 \\
\hline Salicylic acid (S.A.) & 1.88 & 2.49 & 3.19 & 3.98 & 2.89 & 1.33 & 2.04 & 3.21 & 3.85 & 2.61 \\
\hline Ascorbic acid (vit. C) & 2.59 & 3.21 & 4.01 & 4.82 & 3.66 & 2.73 & 3.54 & 4.39 & 4.88 & 3.89 \\
\hline Microbein biofertilizer & 3.91 & 4.62 & 5.11 & 5.23 & 4.72 & 3.99 & 4.68 & 5.15 & 5.27 & 4.77 \\
\hline Microbein + S.A. & 4.21 & 4.83 & 5.18 & 5.31 & 4.88 & 4.33 & 4.91 & 5.21 & 5.38 & 4.96 \\
\hline Microbein + vit. C & 4.35 & 4.91 & 5.28 & 5.41 & 4.99 & 4.39 & 5.09 & 5.30 & 5.44 & 5.06 \\
\hline Microbein + S.A. + vit. C & 4.39 & 5.01 & 5.36 & 5.53 & 5.07 & 4.41 & 5.18 & 5.38 & 5.49 & 5.12 \\
\hline Mean (A) & 3.22 & 3.82 & 4.35 & 4.78 & & 3.26 & 3.96 & 4.52 & 4.86 & \\
\hline L.S.D. at $5 \%$ & \multicolumn{2}{|c|}{ A:0.29 } & B:0.05 & \multicolumn{2}{|c|}{ AB:0.10 } & \multicolumn{2}{|c|}{ A:0.32 } & B:0.02 & \multicolumn{2}{|c|}{$\mathrm{AB}: 0.04$} \\
\hline
\end{tabular}

mentioned by Pal et al. (2015), Pawar et al. (2018) and Al-Hasnawi et al. (2019) on gladiolus, Ramtin et al. (2016) on carnation, Mohamed (2017) on aster, Ahmad et al. (2018) and Nassour et al. (2019) on tuberose plant. The role of ascorbic acid (vit. C) in improving vegetative growth was also investigated by Kasim and Adil (2014) on Freesia hybrid, Mehdikhah et al. (2016) on gerbera, Mohammed et al. (2016) on dahlia plant and Gaber (2019) on Pelargonium zonale plant.
The interaction between both experimental factors $(\mathrm{A} \times \mathrm{B})$ was significant in both seasons for leaf length, leaf number and leaves dry weight. The maximum values of leaf length $(\mathrm{cm})$, number of leaves/plant and leaves dry weight/plant (g), were obtained due to supplying the soil of gladiolus with 15 ton/fed compost in combination with Microbein biofertilizer (M.B.) plus salicylic acid plus vitamin C followed by high level of compost (15 ton/fed) with Microbein biofertilizer (M.B.) 


\section{A.A. Hassan and M.M. Abd El-Azeim}

plus vitamin $C$ then 10 ton/fed compost with the mixture of Microbein biofertilizer (M.B.) plus salicylic acid plus vitamin $\mathrm{C}$ treatments.

\section{Improvements in Flowering parameters:}

Data presented in Tables (4 and 5) show that all compost level treatments caused significant increases in length of spike $(\mathrm{cm})$, spike diameter (mm), spike fresh weight (g), number of florets/spike, lower floret diameter $(\mathrm{cm})$ and lower floret fresh weight (g) in both seasons, in comparison with that of untreated plants. The flowering parameters were gradually increased according to the increase in the levels of compost fertilizer in both seasons. These results are in close agreement with those obtained by Gajbhiye et al. (2013), Abdou and Ibrahim (2015), Kumar et al. (2018) and Beck et al. (2019) on gladiolus, Hatamzadeh and Masouleh (2011) on Cymbidiums, Shahina et al. (2012) on Dianthus caryophyllus, Zarghami and Mahmud (2013)

Table 4. Effect of experimental treatments on length of spike $(\mathrm{cm})$, spike diameter $(\mathrm{mm})$ and spike fresh weight (g) of Gladiolus grandiflorus var. Jester during the first and second seasons.

\begin{tabular}{|c|c|c|c|c|c|c|c|c|c|c|}
\hline \multirow{3}{*}{ Treatments (B) } & \multicolumn{10}{|c|}{ Compost levels (ton/fed) (A) } \\
\hline & \multicolumn{5}{|c|}{$1^{\text {st }} \operatorname{season}(2018 / 2019)$} & \multicolumn{5}{|c|}{$2^{\text {nd }} \operatorname{season}(2019 / 2020)$} \\
\hline & $\mathbf{0}$ & 5 & 10 & 15 & $\begin{array}{c}\text { Mean } \\
\text { (B) }\end{array}$ & $\mathbf{0}$ & 5 & 10 & 15 & $\begin{array}{c}\text { Mean } \\
\text { (B) }\end{array}$ \\
\hline & \multicolumn{10}{|c|}{ Length of spike (cm) } \\
\hline Control & 48.15 & 50.56 & 53.09 & 55.74 & 51.89 & 49.18 & 51.64 & 54.22 & 56.93 & 52.99 \\
\hline Salicylic acid (S.A.) & 51.67 & 54.25 & 56.97 & 59.81 & 55.68 & 52.37 & 54.99 & 57.74 & 60.63 & 56.43 \\
\hline Ascorbic acid (vit. C) & 52.49 & 55.11 & 57.87 & 60.76 & 56.56 & 53.41 & 56.08 & 58.89 & 61.83 & 57.55 \\
\hline Microbein biofertilizer & 53.55 & 56.23 & 59.04 & 61.99 & 57.70 & 54.58 & 57.31 & 60.17 & 63.18 & 58.81 \\
\hline Microbein + S.A. & 54.61 & 57.34 & 60.21 & 63.22 & 58.85 & 55.62 & 58.40 & 63.07 & 66.23 & 60.83 \\
\hline Microbein + vit. C & 55.69 & 58.48 & 61.40 & 64.47 & 60.01 & 56.71 & 59.55 & 62.52 & 65.65 & 61.11 \\
\hline Microbein + S.A. + vit. C & 56.81 & 59.65 & 62.63 & 65.76 & 61.21 & 57.74 & 60.78 & 63.83 & 67.02 & 62.34 \\
\hline Mean (A) & 53.28 & 55.95 & 58.74 & 61.68 & & 54.23 & 56.96 & 60.06 & 63.07 & \\
\hline \multirow[t]{2}{*}{ L.S.D. at $5 \%$} & \multicolumn{2}{|c|}{ A:2.59 } & B:0.22 & \multicolumn{2}{|c|}{ AB:0.44 } & \multicolumn{2}{|c|}{$\mathrm{A}: 2.65$} & B:0.26 & \multicolumn{2}{|c|}{ AB:0.52 } \\
\hline & \multicolumn{10}{|c|}{ Spike diameter (mm) } \\
\hline Control & 0.53 & 0.56 & 0.59 & 0.61 & 0.57 & 0.57 & 0.60 & 0.63 & 0.66 & 0.62 \\
\hline Salicylic acid (S.A.) & 0.57 & 0.59 & 0.63 & 0.66 & 0.61 & 0.61 & 0.64 & 0.67 & 0.71 & 0.66 \\
\hline Ascorbic acid (vit. C) & 0.60 & 0.63 & 0.65 & 0.69 & 0.64 & 0.65 & 0.68 & 0.72 & 0.75 & 0.70 \\
\hline Microbein biofertilizer & 0.64 & 0.67 & 0.70 & 0.74 & 0.69 & 0.69 & 0.73 & 0.76 & 0.80 & 0.75 \\
\hline Microbein + S.A. & 0.68 & 0.71 & 0.75 & 0.78 & 0.73 & 0.74 & 0.78 & 0.82 & 0.85 & 0.80 \\
\hline Microbein + vit. C & 0.72 & 0.75 & 0.79 & 0.83 & 0.77 & 0.79 & 0.82 & 0.87 & 0.91 & 0.85 \\
\hline Microbein + S.A. + vit. C & 0.76 & 0.78 & 0.84 & 0.88 & 0.82 & 0.83 & 0.87 & 0.92 & 0.96 & 0.90 \\
\hline Mean (A) & 0.64 & 0.67 & 0.71 & 0.74 & & 0.70 & 0.73 & 0.77 & 0.81 & \\
\hline \multirow[t]{2}{*}{ L.S.D. at $5 \%$} & \multicolumn{2}{|c|}{ A:0.02 } & B:0.03 & \multicolumn{2}{|c|}{ AB:0.06 } & \multicolumn{2}{|c|}{ A:0.03 } & B:0.04 & \multicolumn{2}{|c|}{ AB:0.08 } \\
\hline & \multicolumn{10}{|c|}{ Spike fresh weight (g) } \\
\hline Control & 7.98 & 8.34 & 8.80 & 9.24 & 8.59 & 8.66 & 9.09 & 9.55 & 10.03 & 9.33 \\
\hline Salicylic acid (S.A.) & 8.46 & 8.88 & 9.33 & 9.79 & 9.12 & 9.20 & 9.66 & 10.14 & 10.65 & 9.91 \\
\hline Ascorbic acid (vit. C) & 8.99 & 9.44 & 9.91 & 10.41 & 9.69 & 9.68 & 10.16 & 10.67 & 11.21 & 10.43 \\
\hline Microbein biofertilizer & 9.48 & 9.95 & 10.45 & 10.97 & 10.21 & 10.26 & 10.77 & 11.31 & 11.87 & 11.05 \\
\hline Microbein + S.A. & 9.99 & 10.49 & 11.01 & 11.56 & 10.76 & 10.78 & 11.34 & 11.91 & 12.50 & 11.63 \\
\hline Microbein + vit. C & 10.53 & 11.06 & 11.60 & 12.19 & 11.35 & 11.40 & 11.97 & 12.57 & 13.19 & 12.28 \\
\hline Microbein + S.A. + vit. C & 11.16 & 11.72 & 12.30 & 12.92 & 12.03 & 11.99 & 12.59 & 13.22 & 13.88 & 12.92 \\
\hline Mean (A) & 9.51 & 9.98 & 10.49 & 11.01 & & 10.28 & 10.80 & 11.34 & 11.90 & \\
\hline L.S.D. at $5 \%$ & \multicolumn{2}{|c|}{ A:0.45 } & B:0.46 & \multicolumn{2}{|c|}{ AB:0.92 } & \multicolumn{2}{|c|}{ A:0.48 } & B:0.50 & \multicolumn{2}{|c|}{$\mathrm{AB}: 1.00$} \\
\hline
\end{tabular}


Table 5. Effect of experimental treatments on number of florets/spike, lower floret diameter (cm) and lower floret weight (g) of Gladiolus grandiflorus var. Jester during the first and second seasons.

\begin{tabular}{|c|c|c|c|c|c|c|c|c|c|c|}
\hline \multirow{3}{*}{ Treatments (B) } & \multicolumn{10}{|c|}{ Compost levels (ton/fed) (A) } \\
\hline & \multicolumn{5}{|c|}{$1^{\text {st }}$ season $(2018 / 2019)$} & \multicolumn{5}{|c|}{$2^{\text {nd }} \operatorname{season}(2019 / 2020)$} \\
\hline & $\mathbf{0}$ & 5 & 10 & 15 & $\begin{array}{c}\text { Mean } \\
\text { (B) }\end{array}$ & $\mathbf{0}$ & 5 & 10 & 15 & $\begin{array}{c}\text { Mean } \\
\text { (B) }\end{array}$ \\
\hline & \multicolumn{10}{|c|}{ Number of florets/spike } \\
\hline Control & 8.10 & 8.34 & 8.59 & 8.85 & 8.47 & 8.38 & 8.65 & 8.94 & 9.24 & 8.80 \\
\hline Salicylic acid (S.A.) & 8.55 & 8.81 & 9.07 & 9.34 & 8.94 & 8.73 & 9.02 & 9.33 & 9.60 & 9.17 \\
\hline Ascorbic acid (vit. C) & 8.89 & 9.15 & 9.43 & 9.71 & 9.30 & 9.19 & 9.49 & 9.81 & 10.13 & 9.66 \\
\hline Microbein biofertilizer & 9.35 & 9.63 & 9.92 & 10.21 & 9.78 & 9.61 & 9.93 & 10.26 & 10.60 & 10.10 \\
\hline Microbein + S.A. & 9.69 & 9.98 & 10.28 & 10.59 & 10.14 & 9.99 & 10.32 & 10.66 & 11.01 & 10.50 \\
\hline Microbein + vit. $\mathbf{C}$ & 10.11 & 10.41 & 10.73 & 10.05 & 10.33 & 10.41 & 10.75 & 11.11 & 11.48 & 10.94 \\
\hline Microbein + S.A. + vit. C & 10.56 & 10.88 & 11.20 & 11.65 & 11.07 & 10.87 & 11.23 & 11.60 & 11.98 & 11.42 \\
\hline Mean (A) & 9.32 & 9.60 & 9.89 & 10.06 & & 9.60 & 9.91 & 10.24 & 10.58 & \\
\hline \multirow[t]{2}{*}{ L.S.D. at $5 \%$} & \multicolumn{2}{|c|}{ A:0.15 } & B:0.16 & \multicolumn{2}{|c|}{ AB:0.32 } & \multicolumn{2}{|c|}{ A:0.19 } & B:0.18 & \multicolumn{2}{|c|}{ AB:0.36 } \\
\hline & \multicolumn{10}{|c|}{ Lower floret diameter (cm) } \\
\hline Control & 6.15 & 6.32 & 6.48 & 6.62 & 6.39 & 6.37 & 6.51 & 6.65 & 6.80 & 6.58 \\
\hline Salicylic acid (S.A.) & 6.34 & 6.46 & 6.60 & 6.73 & 6.53 & 6.60 & 6.75 & 6.89 & 7.05 & 6.82 \\
\hline Ascorbic acid (vit. C) & 6.51 & 6.64 & 6.77 & 6.91 & 6.71 & 6.84 & 6.99 & 7.14 & 7.30 & 7.07 \\
\hline Microbein biofertilizer & 6.71 & 6.84 & 6.98 & 7.12 & 6.91 & 7.11 & 7.27 & 7.43 & 7.59 & 7.35 \\
\hline Microbein + S.A. & 6.90 & 7.03 & 7.18 & 7.32 & 7.11 & 7.33 & 7.49 & 7.66 & 7.81 & 7.57 \\
\hline Microbein + vit. C & 7.08 & 7.22 & 7.37 & 7.51 & 7.30 & 7.57 & 7.74 & 7.91 & 8.00 & 7.81 \\
\hline Microbein + S.A. + vit. C & 7.31 & 7.46 & 7.61 & 7.79 & 7.54 & 7.81 & 7.98 & 8.16 & 8.34 & 8.07 \\
\hline Mean (A) & 6.71 & 6.85 & 7.00 & 7.14 & & 7.09 & 7.25 & 7.41 & 7.56 & \\
\hline \multirow[t]{2}{*}{ L.S.D. at $5 \%$} & \multicolumn{2}{|c|}{ A:0.09 } & B:0.12 & \multicolumn{2}{|c|}{$\mathrm{AB}: 0.24$} & \multicolumn{2}{|c|}{ A:0.12 } & B:0.14 & \multicolumn{2}{|c|}{ AB:0.28 } \\
\hline & \multicolumn{10}{|c|}{ Lower floret weight (g) } \\
\hline Control & 5.56 & 5.72 & 5.89 & 6.07 & 5.81 & 5.61 & 5.78 & 5.95 & 6.13 & 5.87 \\
\hline Salicylic acid (S.A.) & 5.74 & 5.91 & 6.08 & 6.27 & 6.00 & 5.85 & 6.03 & 6.21 & 6.36 & 6.11 \\
\hline Ascorbic acid (vit. C) & 5.97 & 6.14 & 6.33 & 6.52 & 6.24 & 5.98 & 6.16 & 6.34 & 6.53 & 6.25 \\
\hline Microbein biofertilizer & 6.18 & 6.36 & 6.55 & 6.75 & 6.46 & 6.19 & 6.38 & 6.57 & 6.76 & 6.48 \\
\hline Microbein + S.A. & 6.41 & 6.60 & 6.80 & 7.01 & 6.71 & 6.39 & 6.58 & 6.79 & 6.98 & 6.69 \\
\hline Microbein + vit. C & 6.64 & 6.83 & 7.04 & 7.26 & 6.94 & 6.69 & 6.89 & 7.10 & 7.01 & 6.92 \\
\hline Microbein + S.A. + vit. C & 6.89 & 7.09 & 7.31 & 7.54 & 7.21 & 6.92 & 7.12 & 7.34 & 7.59 & 7.24 \\
\hline Mean (A) & 6.20 & 6.38 & 6.57 & 6.77 & & 6.23 & 6.42 & 6.61 & 6.77 & \\
\hline L.S.D. at $5 \%$ & \multicolumn{2}{|c|}{ A:0.12 } & B:0.12 & \multicolumn{2}{|c|}{$\mathrm{AB}: 0.24$} & \multicolumn{2}{|c|}{$\mathrm{A}: 0.14$} & B:0.13 & \multicolumn{2}{|c|}{ AB:0.26 } \\
\hline
\end{tabular}

on petunia, Osman (2016) on gerbera, Prasad et al. (2017) on lily, Hamid et al. (2017) on narcissus plant. A possible explanation to the positive effects of compost fertilizer treatments might be attributed to its stimulative effect on different vegetative growth (Khattab et al., 2017; Abbasi et al., 2020). Better vegetative growth should be directly reflected on various flowering aspects (Manzoor et al., 2019; Niazian and Nalousi, 2020).
Regarding Microbein biofertilizer (M.B.) and/or some antioxidant (salicylic acid and vitamin C) treatments and their combined, data in Tables (4 and 5) revealed that all seven used treatments significantly increased length of spike $(\mathrm{cm})$, spike diameter $(\mathrm{mm})$, spike fresh weight (g), number of florets/spike, lower floret diameter $(\mathrm{cm})$ and lower floret fresh weight (g) compared with untreated plants. The highest values were obtained due to the treatments of Microbein 


\section{A.A. Hassan and M.M. Abd El-Azeim}

biofertilizer (M.B.) plus salicylic acid plus vitamin C.

These finding was similar to those obtained by Srivastava and Govil (2005), Kaushik et al. (2016), Pansuriya et al. (2018) and Chakradhar et al. (2019) on gladiolus, Khan et al. (2009) on tulip, Kumar et al. (2012) on tuberose plant.

These results might be attributed to the direct and/or indirect roles of substances (nutrients, amino acids, vitamins, auxins, cytokinin and gibberellins) (Spernat, 1990 and Nagodawithana, 1991), all those substances have better effects on the plant growth, consequently improving enzymatic system that reflected on the flowering of gladiolus. The role of salicylic acid treatments in increasing flowering aspects parameters was mentioned by Pawar et al. (2018) and Al-Hasnawi et al. (2019) on gladiolus, Ramtin et al. (2016) on carnation, Ahmad et al. (2018) and Nassour et al. (2019) on tuberose plant.

The role of ascorbic acid (vit. C) in promoting flowering was also discussed by Mehdikhah et al. (2016) on gerbera, Mohammed et al. (2016) on dahlia plant and Gaber (2019) on Pelargonium zonale plant. Antioxidants protect plants against damage resulting from aerobic metabolism, photosynthesis and a range of pollutants. It also acts as enzyme co-factor especially hydroxylase enzyme, electron transport, oxalate and tartarate synthesis (Bharaguva, 1991 and Mehdy, 1994; Khattab et al., 2017; Abbasi et al., 2020). The interaction between both experimental factors (factor A and factor B) was significant in both seasons for the studied flowering characters (Fig., 1).

Since the largest length of spike (season one 65.76 and season two 65.76), largest number of florets/spike (season one 11.65 and season two 11.98) and the highest lower floret diameter (season one 7.79 and season two 8.34) were achieved with compost (15 ton/fed) in combination with Microbein biofertilizer plus salicylic acid plus ascorbic acid and these traits are the most important characters for the quality of gladiolus, application of compost and Microbein plus ascorbic acid in combination is recommended. Gladiolus flowers have a high economic value, and if produced with high quality, suitable profitability will follow. In the production process of gladiolus, the quality of the flowers is related to length of spike, length and diameter of lower florets, number of florets/spike and vase life. The quality of vegetative growth parameters is also an important factor to determine the quality of the gladiolus flower (Khattab et al., 2017; Abbasi et al., 2020).

\section{CONCLUSION}

In Egypt, gladiolus is an important cut flower and the importance of gladiolus as a cut flower is increasing day by day in domestic and international exporting markets. Commonly, as stated by the results obtained by this research for important gladiolus flowering characters for instance the largest length of spike, largest number of florets/spike and the highest lower floret diameter, it seems that compost at the rate of 15 ton/fed in combination with Microbein biofertilizer plus salicylic acid plus ascorbic acid can be considered as the best treatment for gladiolus Jester variety production in Egypt. Additionally, this treatment improved gladiolus vegetative growth parameters such as leaf length $(\mathrm{cm})$, number of leaves/plant, leaves dry weight/plant (g). Results of this research indicated that in most cases, the best overall results regarding vegetative growth and flowering aspects were obtained due to the use of compost at the high level (15 ton/fed) in combination with Microbein biofertilizer (M.B.) plus salicylic acid plus vitamin $C$ followed by the high level of compost (15 ton/fed) with the two mixed of Microbein biofertilizer (M.B.) plus vitamin $\mathrm{C}$ then the medium level of compost (10 ton/fed) with the three mixed of Microbein biofertilizer (M.B.) plus salicylic acid plus vitamin C. Gladiolus corms of Jester variety (Gladiolus gradiflorus) agricultural adaptability to the Egyptian conditions is 


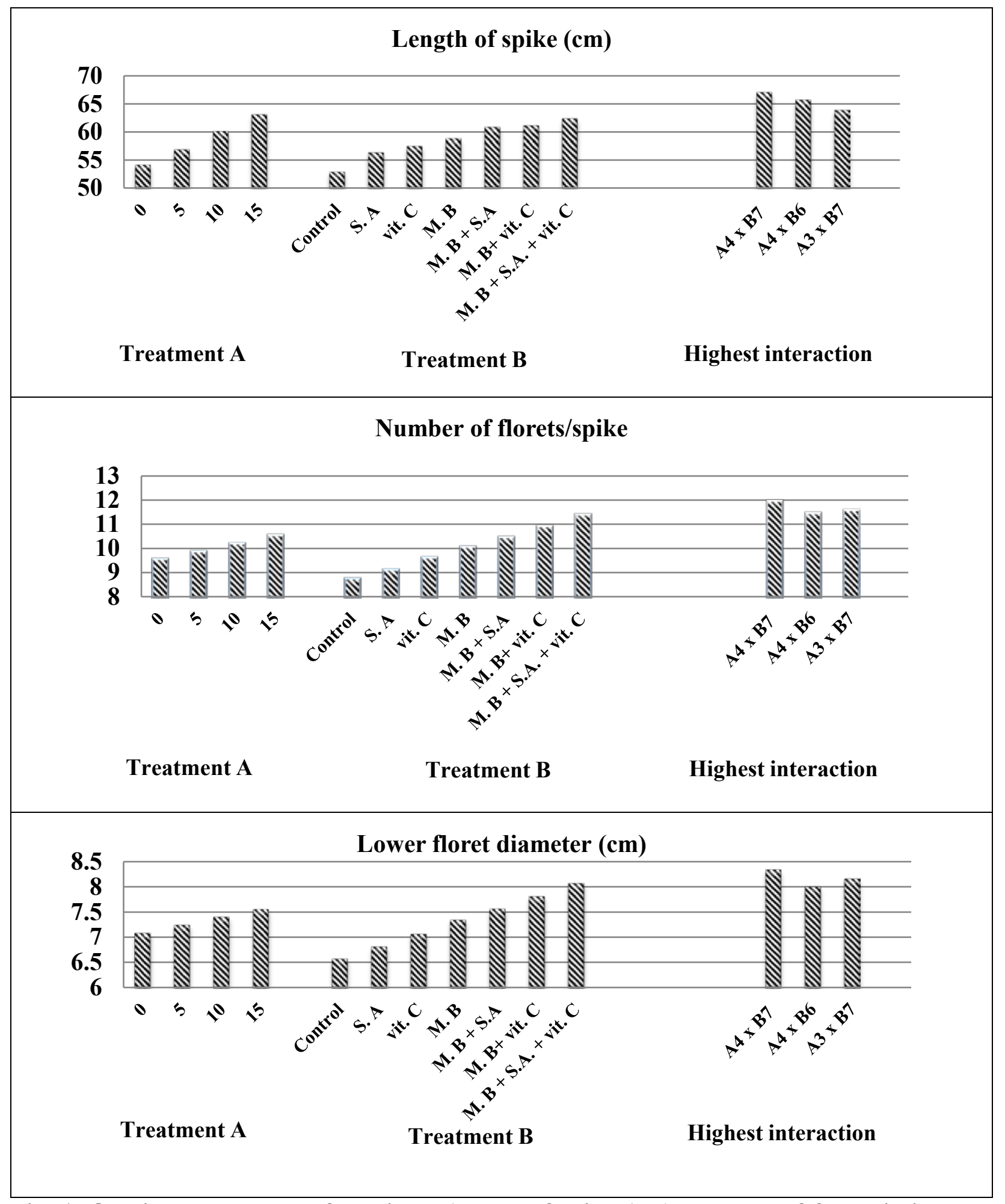

Fig. 1. Quality parameters of gladiolus (length of spike (cm), number of florets/spike and lower floret diameter $(\mathrm{cm})$ as affected by experimental treatments, compost 15 ton/fed + M.B. + S.A. + V.C (A4 x B7); compost 15 ton/fed +M.B. + V.C (A4 x B6); compost 10ton/fed + M.B. + S.A. + V.C (A3 x B7). 


\section{A.A. Hassan and M.M. Abd El-Azeim}

increased as well as increasing high potentials of its flowers exporting.

\section{REFERENCES}

Aashutosh, M.K.; Malik, S.; Singh, M.K.; Singh, S.P.; Chaudhary, V. and Sharma, V.R. (2019). Optimization of spacing, doses of vermi-compost and foliar application of salicylic acid on growth, flowering and soil health of chrysanthemum (Dendranthema grandiflora, Tzvelev) cv. "Guldasta”. International J. of Agric., Environ. and Biotech., 12(3):213-224.

Abbasi, F.; Khaleghi, A.; Khadivi, A. and Solgi, M. (2020). The effect of benzyladenine and salicylic acid on morphological and biochemical traits of asiatic hybrid Lilium 'Navona'. Gesunde Pflanzen, 72:219-225. https://doi.org/10. 1007/s10343-020-00504-8

Abdel Aziz, G.N.; Taha, L. and Ibrahim, S.M.M. (2009). Some studies on the effect of putrescine, ascorbic acid and thiamine on growth, flowering and some chemical constituents of gladiolus at Nubaria. Ozean J. of Applied Sci., 2(2): 169-179.

Abdou, M.A.H.; Badran, F.S.; Ahmed, E.T.; Taha, R.A. and Abdel-Mola, M.A.M. (2018). Effect of compost and some natural stimulant treatments on: I. Vegetative growth and flowering aspects of (Gladiolus grandiflorus cv. Peter Pears) plants. Proc. of the $4^{\text {th }}$ Conf. of SSFOP, Scientific J. Flowers \& Ornamental Plants, 5(2):105-114.

Abdou, M.A.H. and Ibrahim, T.I.E. (2015). Response of gladiolus cV. Carmen to compost, biofertilization and some vitamin treatments. Proc. of the $1^{\text {st }}$ Conf. of SSFOP, Scientific J. Flowers \& Ornamental Plants, 2(1):1-10.

Abduallah, A.M.A. (2019). Effect of Compost, Potassium Silicate and Amino Acids on Iris Plants. M.Sc. Thesis, Fac. Agric., Minia Univ., Egypt, 147 p.
Abo Leila, B. and Eid, R. (2011). Improving gladiolus growth, flower keeping quality by using some vitamins application. Journal of American Science, 7(3):169174.

Ahmed, A.S.A. (2013). Physiological Studies on Gladiolus Plant. M.Sc. Thesis, Fac. Agric. Minia Univ. Egypt, 188 p.

Ahmad, M.; Faiz, P.; Haq, S.I.; Nawaz, A.; Washa, P. and Ullah, Z. (2018). Foliar application of salicylic acid enhanced the production of tuberose (Polianthes tuberosa, L.). International J. of Agric. and Environ. Res., 4(4):191-197.

Al-Hasnawi, H.A.; Hussein, J.K. and Khaleel, T.H. (2019). Effect of growth regulators and preservative solution on vase life and water relation of Gladiolus hybrid, L. after cut flowers. Iraqi Journal of Agricultural Sciences, 50:182-191.

Attia, K.E.; Elbohy, N.F.S. and Ashour, N.A.M. (2018). Response of tuberose plants (Polianthes tuberosa. L.) to chemical and bio fertilization and their effect on vegetative growth, flowering and chemical composition under sandy soil conditions. Scientific J. Flowers \& Ornamental Plants, 5(3):261-273.

Avinash, M.; Swamy, M.; Vendan, K.T.; Santhosh, G.P. and Hugar, A. (2019). Influence of Azosprillum isolates on growth parameters of tuberose (Polianthes tuberosa, L.) cv. Mexican Single. Int. J. Curr. Microbiol. App. Sci., 8(3):664-670.

Baruati, D.; Talukdar, M.C. and Kumar, V. (2018). Effect of organic manures and biofertilizers on growth and yield of gladiolus (Gladiolus grandiflorus, L.). International Journal of Chemical Studies, 6(5):2529-2532.

Beck, S.K.; Beck, M.K. and Agrawa, P. (2019). Analyzing different spacing and fertilizer applications interaction effect on growth, flowering and yield of gladiolus (Gladiolus grandiflorus, L.). 
Int. J. Curr. Microbiol. App. Sci., 8(4): 707-715.

Bharaguva, P.L. (1991). Proceedings of the International Workshop on Orobanche Research. Obermarchatal, FRG.

Bohra, M. and Nautiyal, B.P. (2019). Effect of plant density and INM on vegetative, floral and yield attributes of gladiolus (Gladiolus grandiflorus, L.). Agricultural Reviews, 40(1) 2019: 45-52.

Chakradhar, P.; Bohra, M.; Goutham, K. B. K. and Upadhyay, S. (2019). Response of biofertilizers on floral and yield attributing parameters of gladiolus (Gladiolus grandiflorus, L.) var. Arka Amar under hill conditions of Uttarakhand. Int. J. Pure App. Biosci. 7(1): 157-161.

Chandar, I.; Rawat, I.; Lakhawat, S.S. and Yadav, K.K. (2012). Effect of organic manures and biofertilizers on the yield parameters of Gladiolus cv. White Prosperity. Ecol., Environ. and Conservation Paper, 18(1): 91-94.

Dadarwall, L.R.; Yadv, L.S. and Sindhu, S.S. (1997). Biofertilizer production: Technology Prospects in biotechnological approach in soil microorganisms for sustainable crop production. Scientific Publishers, Jodhpur., India. P.: 323 - 337.

Dalve, P.D.; Mane, S.V. and Nimbalkar, R.R. (2009). Effect of biofertilizers on growth, flowering and yield of gladiolus. The Asian J. of Hort., 4(1):227-229.

De-Hertogh, A. and Le Nard, M. (1995). Botanical aspects of flower bulbs. In: De Hertogh, A.A. and Le Nard, M. (eds.), The Physiology of Flowering Bulbs. Burlington, Elsevier, p. 7-28.

Dewantier Da Cruz, L.R.; Ludwig, F.; Steffen, G.B.K. and Maldaner, J. (2018). Development and quality of gladiolus stems with the use of vermicompost and Trichoderma sp. in substrate. Scientific Article J., 24(1):70-77.
El-Sayed, A.; El-Hanafy, H.; Nabih, A. and Atowa, D.I. (2012). Raising Freesia refracta cv. Red Lion corms from cormels in response to different growing media and actosol levels. J. of Hort. Sci. Ornamental plants, 4(1): 89-97.

Ezhilmathi K, Singh V.P.; Arora, A. and Sairam, R.K. (2007). Effect of 5sulfosalicylic acid on antioxidant activity in relation to vase life of gladiolus cut flowers. Plant Growth Regul., 51:99-108

Fayaz, K.; Khan, F.U.; Nazki, I.T.; MadinatUl-Nisa, P.V. and Singh, V.K. (2018). Effect of integrated nutrient application on yield and bulb production characters in tulip (Tulipa gesneriana, L.) cv. "Red Beauty”. Int. J. Curr. Microbiol. App. Sci., 7:190-195.

Gaber, K.M. (2019). Vegetative and flowering growth of geranium as affected by mineral fertilization and ascorbic acid foliar application. Middle East J. Appl. Sci., 9(1):220-230.

Gadagi, R.S.; Krishnaraj, P.U.; Kulkarni, J.H. and Tongmin, Sa. (2004). The effect of combined Azospirillum inoculation and nitrogen fertilizer on plant growth promotion and yield response of the blanket flower (Gaillardia pulchella). Scientia Horticulture, 100:323-332.

Gajbhiye, B.R.; Vetal, R.A.; Puri, A.N. and Adsul, P.B. (2013). Effect of FYM, N, P and $\mathrm{K}$ levels on growth and flowering of gladiolus (Gladiolus grandiflorus) cV White Prosperity. The Journal of Rural and Agricultural Research,13(2):94-97.

Hamid, N.S.; Siddique, M.A.A.; Fahmeeda, S.; Shameen, I. and Ahmad, W.M. (2017). Influence of different organic manures and bio-fertilizers on morphological, floral and bulb traits of Narcissus (Daffodil cv. "Salome"). International Journal of Agriculture Sciences, 9(10):3989-3992.

Hatamzadeh, A. and Masouleh, S.S. (2011). The influence of vermicompost on the 


\section{A.A. Hassan and M.M. Abd El-Azeim}

growth and productivity of Cymbidiums. Caspian J. Env. Sci., 9(2):125-132.

Hauwaka, F.I.A. (2000). Effect of using single and composite inoculation with Azospirillum brasilense, Bacillus megaterium var. phosphaticum and Glomus marcocarpus for improving growth of Zea mays. J. Agric. Sci. Mansoura Univ., 25 (1):239- 252.

Hedge, D.M.; Dwivedi, B.S. and Sudhakara, B.S.S. (1999). Biofertilizers for cereal production in India. A review - Indian J. Agric. Res., 69(2):73-83.

Jabbar, A.; Tahranifar, A.; Shuor, M. and Nemati, S.H. (2018). Effect of different media on some growth, flowering and biochemical parameters of two cultivars of gladiolus (Gladiolus grandifloras, L.) under soilless conditions. Journal of Ornamental Plants, 8(3,):205-215. http://jornamental.iaurasht.ac.ir/article_5 42591.html

Jackson, M.L. (1973). Soil Chemical Analysis Englewood Cliffs., New Prentice-Hall INC., New York, 498 p.

Judais, V. and Rinaldi, S. (2001). Organic fertilizers in melon: the dynamic of nitrogen. PHM Revue Horticole, 431:1720 (Hort. Abst., 72 (7):6385).

Kabir, A.K.M.R.; Iman, M.H.; Mondal, M.M.A. and Chowdhury, S. (2011). Response of tuberose to integrated nutrient management. J. Environ. Sci. \& Natural Resources, 4(2):55-59.

Karim, K.P.; Kumar, N.V.; Raghupati, B. and Pal, A.K. (2017). Effect of biostimulants on growth and floral attributes of tuberose (Polianthes tuberosa, L.) cv. Prajwal. Int. J. Curr. Microbiol. App. Sci., 6(6):2557-2564.

Kashyap, S.K. (2016). Effect of Biofertilizers with Different Levels of Nitrogen and Phosphorus on Growth and Flower Yield of Gladiolus (Gladiolus grandiflorus, L.). M.Sc. Thesis, College of Agric., Indira Gandhi Agricultural University, India, 74 p.
Kasim, J.Y. and Adil, A.M. (2014). Effect of gibberellic acid, spraying micronutrient and ascorbic acid in the vegetative growth, flowering of Freesia hybrida cv. Prominence. Journal of Kirkuk University for Agricultural Sciences, 5(1):50-64.

Kaushik, H.; Kumar, J.; Singh, J.P.; Singh, R.K.; Rajbeer, R. and Kumar, S. (2016). Effect of $\mathrm{GA}_{3}$ and biofertilizers on growth and flowering in gladiolus (Gladiolus floribundus, L.) cv. American Beauty. Adv. Res. J. Crop Improve, 7(1):52-55.

Khalil, A.R.M. (2015). Physiological Studies on Gladiolus Plant. M. Sc. Thesis, Fac. Agric. Minia Univ., 146 p.

Khan, F.U.; Saddique, M.A.A.; Khan, F.A. and Nazki, I.I. (2009). Effect of biofertilizers on growth, flower quality and bulb yield in tulip (Tulipa gesneriana). Indian J. of Agric. Sci., 79(4):248-251.

Khattab, M.; El-Torky, M.; Torabeih, A. and Rashed, H. (2017). Effect of some chemicals on vase life of gladiolus cut flowers. Alexandria Science Exchange Journal, 38(3):588-598.

Kiran, M.; Baloch, A. and Khan, M. (2013). Effect of different growing media on the growth and development of dahlia (Dahlia pinnata) under the Agro-climatic condition of Dera Ismail Kkan. Pakistan J. of Biol. Sci., 10:4140-4143.

Kumar, C.T. and Saravanan, S.S. (2019). Effect of FYM, vermicompost and poultry manure on vegetative growth, spike quality and flower yield of gladiolus (Gladiolus grandiflorus, L). Journal of Pharmacognosy and Phytochemistry, 8(4):523-527.

Kumar, J.; Kumar, P and Pal, K. (2012). Effect of biofertilizer and micronutrient on growth and flowering of tuberose (Polianthus tuberose, L.) cv. Pearl Double. Agric. Sci. Digest., 32(2):164167. 
Kumari, S.; Kumar, P. and Singh, C.P. (2018). Effect of pre-harvest sprays of hormones on spike quality and vase life of Asiatic lilium cv. Tresor. The Pharma Innovation Journal, 7(6):470-473.

Lepcha, B.; Nautiyal, M.C. and Rao, V.K. (2007). Variability studies in gladiolus under mid hill conditions of Uttarakhand. Journal of Ornamental Horticulture, 10(3):169-172.

Manzoor, A.; Ahmad, T.; Bashir, M.A.; Hafiz, I. A. and Silvestri, C. (2019). Studies on colchicine induced chromosome doubling for enhancement of quality traits in ornamental plants. Plants (Basel). 8(7):194. https://doi.org /10.3390/plants8070194.

Mehdikhah, M.; Onsinejad, R.; Ilkaee, M.N. and Kaviani, B. (2016). Effect of salicylic acid, citric acid and ascorbic acid on post-harvest quality and vase life of gerbera (Gerbera jamesonii) cut flowers. Journal of Ornamental Plants, 6(3):181-191.

Mehdy, M.C. (1994). Active oxygen species in plant defense against pathogens. Plant physiology, 105:467-472. https://doi.org /10.1104/pp.105.2.467

Mirkalae, S.M.; Ardebili, Z.O. and Mostafavi, M. (2013). The effects of different organic fertilization on the growth of Lilium longiflorum. Inter. Res. J. of Applied and Basic Sci., 4(1):181186.

Mohamed, Y.F.Y. (2017). Effect of some growth stimulants on growth, flowering and postharvest quality of Aster (Symphyotrichum novi-belgii, L.) cv. Purple Monarch. Middle East J. Agric. Res., 6(2):264-273.

Mohammed, S.A.; Abd-Allatif, S.A. and Obaid, A.A. (2016). Effect of foliar application with potassium sulphate and ascorbic acid on growth and flowering of dahlia (Dahlia variabilis, L. cv. Arizona). Diyala for Agricultural Sciences Journal, 8(1):232-248.
MSTAT-C (1986). A Microcomputer Program for the Design Management and Analysis of Agronomic Research Experiments (Version 4.0), Michigan State Univ., U.S.A.

Munne-Bosch, S. and Algere, L. (2002). The function of tocopherol and tocotrienol in plants. Crit. Rev. Plant Sci., 21:31-57.

Nagodawithana, W.T. (1991). Yeast Technology $2^{\text {nd }}$ ed. Van Nostrand Reinhold, New York, USA, 273 pp.

Nassour, M.; Haifa, S. and Ahmad, N. (2019). Effect of humic and salicylic acids on growth, flowering and bulb production of tuberose plants. Tishreen University Journal for Research and Scientific Studies - Biological Sciences Series, 14(5):51-66.

Niazian, M. and Nalousi, A.M. (2020). Artificial polyploidy induction for improvement of ornamental and medicinal plants. Plant Cell, Tissue and Organ Culture, 142:447-469. https://doi.org/10.1007/s11240-02001888-1.

Osman, S.K.A.A. (2016). Effect of Some Biofertilizers and Compost on Growth and Flowering of Gerbera (Gerbera jamesonii, Bolus). M.Sc. Thesis, Khartoum Univ., Sudan, 40 p.

Page, A.L.; Miller, R.H. and Keeney, D.R. (1982). Methods of soil analysis; 2. Chemical and Microbiological Properties, American Soc. of Agronomy, Madison, Wisconsin, USA, 1159 p.

Pal, V.; Ram, M. and Kumar, M. (2015). Effect of various levels of spacing and salicylic acid treatment on vegetative growth and flowering of gladiolus (Gladiolus grandiflora, L.) cv. White prosperity. South Asian J. Food Technol. Environ., 1(1):101-104.

Pandey, A.; Singh, A. and Sisodia, A. (2013). Effect of vermicompost and biocontrol agents on growth and flowering of gladiolus cv. J.V. Gold. The Asian Journal of Horticulture, 8(1):46-49. 


\section{A.A. Hassan and M.M. Abd El-Azeim}

Pandey, S.K.; Kumari, S.; Singh, D.; Singh, V.K. and Prasad, V.M. (2017). Effect of biofertilizers and organic manures on plant growth, flowering and tuber production of dahlia (Dahlia variabilis, L.) cv. S.P. Kamala. Int. J. Pure App. Biosci., 5(2):549-555.

Pansuriya, P.B.; Varu, D.K. and Viradia, R.R. (2018). Effect of biostimulants and biofertilizers on growth, flowering and quality of gladiolus (Gladiolus grandiflorus, L.) cV. American Beauty under greenhouse conditions. International Journal of Chemical Studies, 6(2):2191-2196.

Pattnaik, S. (2016). Effect of Organic Manures on Growth and Flowering of Tuberose (Polianthes tuberosa) cv. Phule Rajani. M.Sc. Thesis, Orissa University of Agriculture and Technology, India, 83 p.

Pawar, A.; Chopde, N. and Nikam, B. (2018). Effect of thiourea and salicylic acid on growth, flowering and yield of gladiolus. International Journal of Chemical Studies, 6(4):2104-2106.

Prasad, L.; Saravanan, S.; Lall, D. and Singh, V.K. (2017). Effect of organic manure and inorganic fertilizer on plant growth and flower yield of Asiatic lily (Lilium longiflorum) sp. Zephyranthes. Environment \& Ecology J., 35 (2A): 929932.

Preetham, S.P.; Srivastava, R. and Bintory, M.A. (2017). Effect of organic manures and bio-fertilizers on vegetative growth in tuberose (Polyanthus tuberosa) var. Shringar. Int. J. Pure App. Biosci., 5(6):996-999.

Rajaei, N. and Onsinejad, R. (2014). Effect of municipal solid waste compost and gibberellic acid on morphological and physiological traits of tulip (Tulipa spp.) cV. Bright Parrot. European Journal of Experimental Biology, 4(1):361-368.

Ramtin, A.; Kalatejari, S.; Naderi, R. and Matinizadeh, M. (2016). Effect of pre- harvest foliar application of benzyl adenine and salicylic acid on carnation cv. spray and standard. Biological Forum - An International Journal, 7(2):955-958.

Ramzan, S.; Hassan, I. and Mushtaq, S. (2018). Improvement in quality and vase life of iris flower by salicylic acid. Asian Journal of Advances in Agricultural Research, 5(1):1-5.

Saber, M.S.M. (1997). Biofertilized Farming System. Proceeding of the Training Course on Bio-Organic Farming Systems for Sustainable Agriculture, pp. 16-72.

Sathyanarayana, E.; Patil, S.; Bahubali, M. and Chawla, S.L. (2018). Effect of INM on gladiolus (Gladiolus grandiflorus, L.) cv. American Beauty under Navsari and Tansa Conditions. Int. J. Pure App. Biosci., 6(4):48-55.

Shahina, Y.; Younis, A.; Rayit, A.; Ateif, R. and Shabeer, S. (2012). Effect of different substrates on growth and flowering of Dianthus caryophyllus cv. Chauband Mixed. American-Eurasian J. Agric. and Environ. Sci., 12(2):249-258.

Spernat, J.I. (1990). Nitrogen Fixing Organisms, Pure and Applied Aspects. Springer, Netherlands, 256 p.

Srivastava, R and Govil, M. (2005). Influence of biofertilizers on growth and flowering and yield in Gladiolus cv. American Beauty. Proc. of the International Conference and Exhibition on Soilless Culture, Singapor, ActaHort, 742:183-188.

Srivastava, R.; Preetham, S.P. and Chand, S. (2014). Effect of organic manures and biofertilizers on vegetative, floral and post-harvest attributes in tuberose (Polianthes tuberosa) var. Shringar. Asian J. Biol. Life Sci., 3(1):6-9.

Taiwo, L.B.; Adediran, J.A.; Ashaye, O.A.; Odofin, O. and Oyadoyin, A.J. (2002). Organic okra (Abolmoschus esculentus): its growth, yield and organoleptic properties. Nutrition \& Food Science, 
32(415):180-183. (Hort. Abst., 72(12):10918).

Tamrakar, S.K.; Singh, P.; Kumar, V. and Tirkey, T. (2018). Effect of gibberellic acid, salicylic acid, cow urine and vermiwash on corm production of Gladiolus cv. Candyman. Int. J. Curr. Microbiol. App. Sci., 6:677-686.

Tirkey, P.; Kullur, L.R. and Prasad, V.M. (2017). Effect of organic and Inorganic source of N.P.K on growth and yield parameters of (Gladiolus grandiflorus) cv. Jester. Journal of Pharmacognosy and Phytochemistry, 6(5):1004-1006.

Zarghami, M. and Mahmud, S. (2013). Effects of vermi-compost and two bacterial biofertilizers on some quality parameters of petunia. Not. Sci. Biol., 5(2):226-231.

Zehra, S.; Ahlawat, V.P. and Sehrawat, S.K. (2017). Studies on efficacy of biofertilizers for nutrient management in gladiolus. Bull. Env. Pharmacol. Life Sci., 6(3):84-89.

\section{تأثيرات معاملات الكمبوست والسماد الحيوي و/أو بعض مضادات الأكسدة على نباتات الجلاديولس

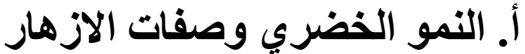

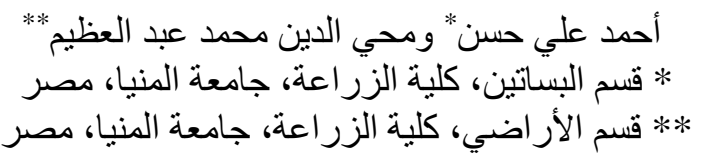

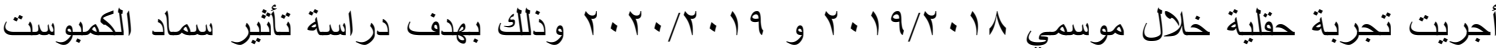

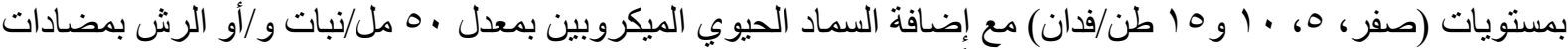

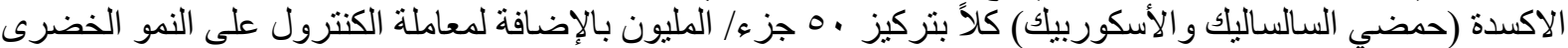

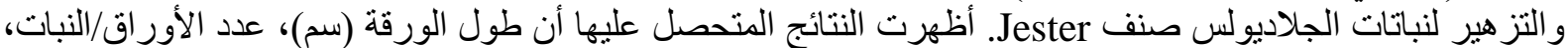

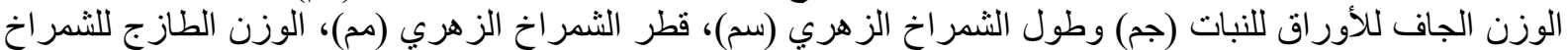

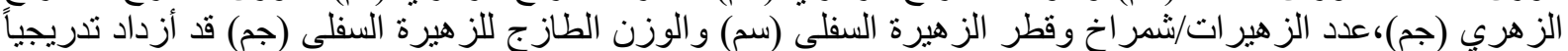

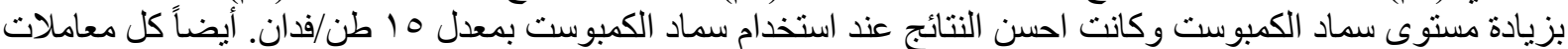

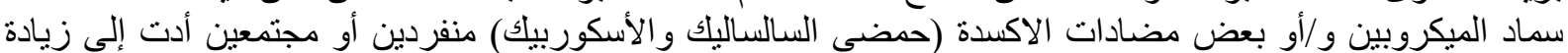

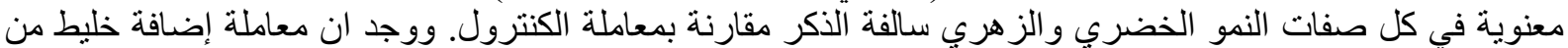

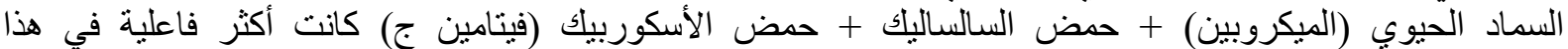

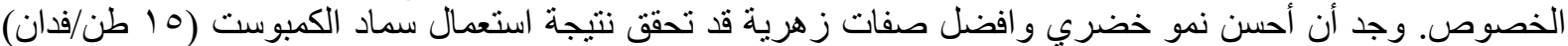

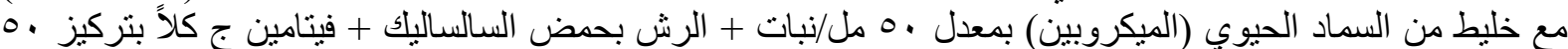

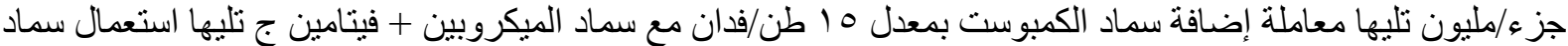

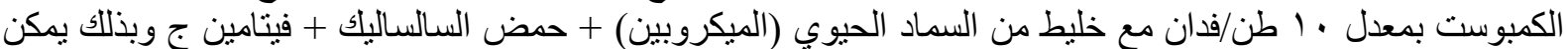

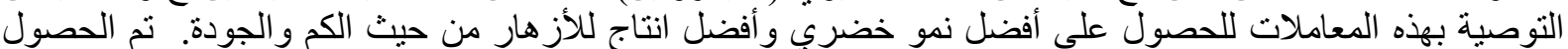

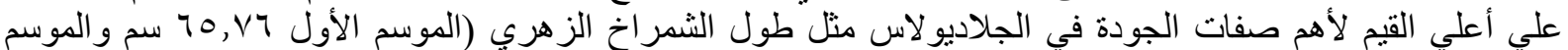

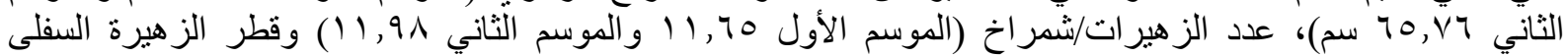

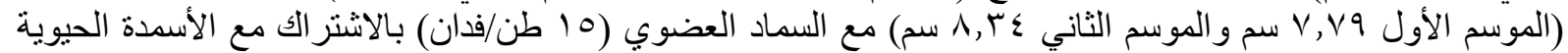

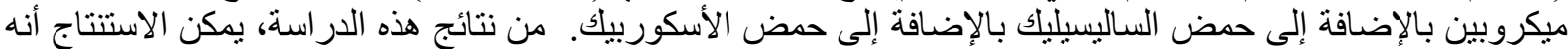

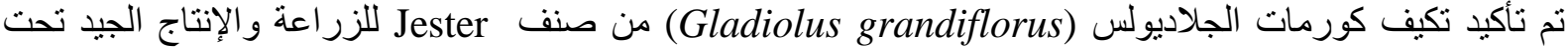
الظروف البيئية المصرية. 